Article

\title{
Constructing an Evaluation Framework for Eco-Museum Operations-Management Performance, Based on the Case of Jhushan, Taiwan
}

\author{
Kuo-Wei Hsu ${ }^{1}$, Meng-Li Lin ${ }^{1}$, Jen-Chih Chao ${ }^{2, *(D)}$ and Shu-Fang Huang ${ }^{1}$ \\ 1 Department of Landscape and Urban Design, Chaoyang University of Technology, Taichung city 41349, \\ Taiwan; kwhsu@cyut.edu.tw (K.-W.H.); menglin@cyut.edu.tw (M.-L.L.); s10428601@gm.cyut.edu.tw (S.-F.H.) \\ 2 Architecture and Urban Design Program, Department of Architecture, Chaoyang University of Technology, \\ Taichung city 41349, Taiwan \\ * Correspondence: jenchihchao@gmail.com; Tel.: +886-4-2332-3000
}

Received: 14 May 2018; Accepted: 6 June 2018; Published: 9 June 2018

\begin{abstract}
The bamboo-art industry in Taiwan's Jhushan Township is inseparable from local life. In the face of local industrial-development difficulties in smaller towns, the Taiwan government aimed to achieve a range of (re)development goals using eco-museums as collaboration platforms and required such museums to combine their operations management with cultural preservation, local industrial development, and local residents' goals. As such, the likely future performance of such operations management has emerged as a crucially important factor in decision-making about whether such museums should be constructed. This study, therefore, reviews the relevant literature on the operations-management performance of museums, with special attention to eco-museums, and proposes an operations-management performance measurement framework for eco-museums based on that review and a two-stage questionnaire administered to experts. The first stage utilized the Fuzzy Delphi Method, which focuses on impact factors, and the second, the Analytica Network Process Method, deals with performance factors. The results indicate that the key impacts on the performance of eco-museums and their operations management were, in order of importance, (1) community symbiosis, (2) cultural inheritance, and (3) regional revitalization. The preservation of cultural heritage, local identity, and community participation are the most important criteria in the operations management of eco-museums, and Jhushan Town can promote such museums through these guidelines.
\end{abstract}

Keywords: eco-museum; operation management performance; bamboo craft

\section{Introduction}

From the perspective of the history of Taiwan, the characteristic bamboo crafts of the Jhushan Township emerged to fill basic day-to-day needs. Over time, however, the range of skills and artistry involved grew enormously, and the sector attained a central place in people's economic and emotional lives, until its recent decline due to competition from plastic products and shifts in lifestyle patterns.

The early residents of Jhushan combined bamboo resources and traditional techniques to produce building materials, furniture, woven products, and household appliances and exported them all over the country. This development process was deeply embedded in Jhushan people's traditional lifestyle, local culture, and indeed, the land itself. The bamboo-crafts industry remains strongly representative of the locality, and-much like long-term residents-is marked by memories of changes in daily life.

Various local organizations have actively promoted Jhushan's bamboo crafts and its local culture, and in the process, actively bound the two even more closely together. The public sector has likewise 
demonstrated an interest in developing bamboo art beyond its core crafts, and into a tool for meeting the locality's expanding economic and cultural needs. At the time of writing, Jhushan has not yet established a bamboo eco-museum, but plans for one are at an advanced stage.

The eco-museum emphasizes the importance of residents' self-consciousness and participation. Jhushan still has a rich area of bamboo forest, and bamboo crafts remain an important factor driving the local economy and development, reinforced by bamboo-arts training classes, bamboo-crafts training programs, and diversified community crafts and planting programs, as well as by various types of bamboo art activities and even the active assistance of governmental and non-governmental organizations.

In 1980, a new wave of local government and scholars emphasized the revitalization and celebration of local ethnic groups and local autonomy and proposed key requirements for the preservation of cultural heritage and regional rejuvenation, and the subversion of the concepts and operations management of traditional museums [1]. This trend culminated in the creation of more than six dozen eco-museums, amid the active involvement of the state; it is widely hoped that the establishment of such a museum in Jhushan will provide an opportunity for local redevelopment. While traditional museums focus on the preservation of objects, eco-museums extend this process into the daily lives, collective memory, and oral discourse of the people. In other words, all cultural representations are heritages that eco-museums can potentially preserve, and all can help the local residents to build a sense of identity. The key to this process is to understand the meanings of the objects rather than the objects themselves, and building such understandings can serve as a catalyst to promote community. The preservation of cultural heritage has a considerable impact on residents' identity, and can also promote community participation. At present, however, Taiwan's eco-museums are still dominated by the local government and its associated rules, decrees, and planning restrictions, and they have many financial difficulties. Yet, academic research on these museums has mostly been limited to case studies of their roles in local-development strategies and the application of museum theory [2-5]. Therefore, the present work examines the operations management of Taiwanese eco-museums generally in light of their economic predicament, with a view to improving it by focusing on their under-researched and under-theorized potentials for community symbiosis, external-environment operations management (that is, outside the venues), and the preservation of culture and industry. More specifically, the purposes of this study are (1) to establish the impact factors of eco-museum operations management; and (2) to construct an operations-management performance measurement framework for such museums. The geographic scope of this study is shown in Figure 1. 


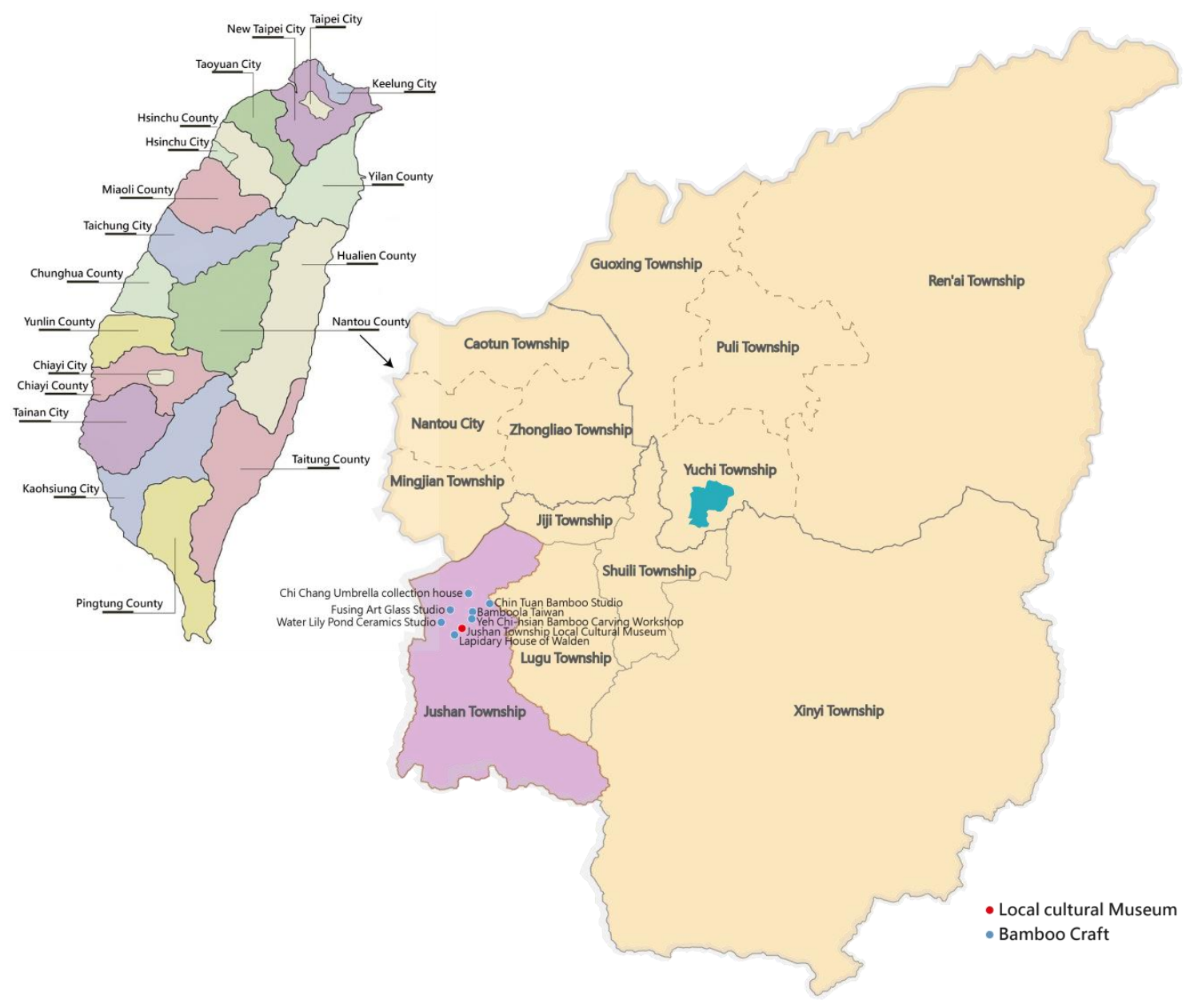

Figure 1. Jhushan of the Nantou County, Taiwan. Produced by the authors, sources: [6].

\section{Literature Review}

\subsection{Definition of Eco-Museums}

As defined by Riviere, an eco-museum - whose subject matter may natural, a human heritage, or both-is a tool for cultivating, shaping, and operating local government and the local population in an instrument conceived, fashioned and operated jointly. It provides personnel, equipment, and resources, while enabling local residents to demonstrate their ambitions, knowledge, and personal strengths. As such, the eco-museum is a mirror in which a community can see itself and, therefore, deal with its problems and strive for something better. At the same time, it is a window that allows visitors to gain a deep understanding of local industries, customs, and characteristics [7]. Ecomuseums in Scandinavia have few of the markers for a museum in regards to the ICOM definition: (collect, research, preserve) they appear more like "historical societies", outside but sometimes connected to an established museum institution [8]. For Chang, eco-museums emphasized the importance of residents' self-interest and ambiguity, and differed from traditional ones in five key ways: (1) they are "bottom up" rather than "top down" in terms of their management; (2) they operate "from outside in" rather than "from the inside out"; (3) they abandon the grand discourses of the past and focus instead on pluralism and community narratives; (4) they are people-oriented rather than object-oriented; and (5) they are present- or future-oriented rather than past-oriented [9]. 


\subsection{Definition of Performance}

Chen et al. defined performance as the product of the interaction between the environment, leadership, and organizational components [10]. Similarly, Chiou used the term to refer to the results of the activities of an organization and its personnel [11]. For Chen et al., performance was the degree to which an organization achieved its strategic goals [12], while Chan et al. used it as a representation of workers' behavior. In short, it is a highly flexible concept, but most definitions are centered on the outcomes of an organization's program [13]. In the specific case of museums, Lin argued that, though mostly run on a non-profit basis, these institutions were still business organizations, and that their performance should, therefore, be measured strictly in terms of costs and profits [14]. The present research disagrees fundamentally with that view. Museums differ from business enterprises and any accurate or useful assessment of their performance must take into account a much more extensive range of performance factors.

\section{Research Methods}

\subsection{Research Process}

As noted above, this study aims to contribute to local-redevelopment policies and strategies by arriving at a clearer picture of the operations-management performance of eco-museums, with particular reference to local government and non-governmental organizations in the Jhushan Township. Based on the foregoing review of the relevant literature on eco-museums and operations-management performance, its research approach was divided into two main phases. First, using the Fuzzy Delphi Method (FDM), experts were invited to answer questionnaires on eco-museums' operations-management performance indicators; and second, having summarized the indicators arrived at in the first phase, it adopted the Analytica Network Process Method (ANPM) to base a local-redevelopment strategy around Jhushan's bamboo crafts. The ANPM was created to provide interdependency and feedback in response to a broad range of decision-making problems in the real world. In contrast to the analytic hierarchy process (AHP), it has a decentralized pattern similar to that of the Internet, and its goal is to foster optimal decisions via internal interdependence among all goals, criteria, and plans through the use of ratio scales. The research process is shown in Figure 2.

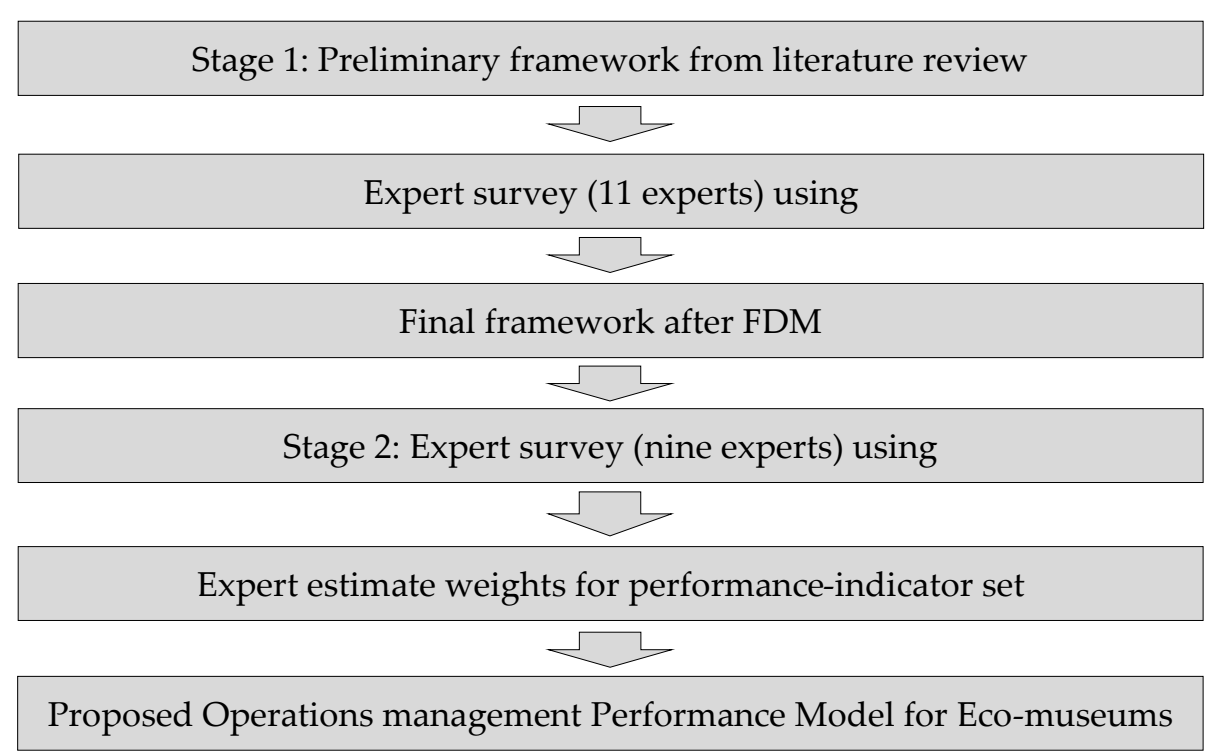

Figure 2. The research process. 
Zhang et al. found that the market acceptance of low-impact housing-design strategies in the tropics was enhanced when key design factors were identified in combination with user needs using FDM. However, the number of samples and the selection of experts are important factors influencing the FDM results, which rely on the achievement of these experts' consensus on the issue at hand [15]. Dalkey and Helmer recommended panels of between 10 and 30 experts to minimize error values and obtain the highest experimental reliability [16]. Delbecq et al. further showed that, provided the background of the experts was homogeneous, 10 to 15 could meet researchers' needs. In the present study, 11 experts-two from the public sector, two from the private sector, and seven from academia-participated in the FDM process [17]. The purpose of ANPM is to help establish appropriate design strategies by integrating user-requirements weights into key design factors. Liu and Chiu showed that creative industries can improve urban competitiveness, arrive at relevant assessment indicators, and formulate policies for the development of creative industries. First, FDM was used to determine positive-impact indicators for evaluating the competitiveness of creative industries in cities. Subsequently, AHP and ANP were combined to establish a policy-evaluation model that urban governments can use for the development of these industries [18]. Kao et al. used expert questionnaires to investigate sustainable-development policies aimed at preventing disasters and analyzed the results using FDM and ANPM, finding that disaster-prevention strategies should be given a higher priority in urban planning to ensure appropriate emergency responses [19]. Wang et al., noting an increasing trend in Taiwan for coastal tourism projects, also made use of the FDM and fuzzy analytic hierarchy process (FAHP) methods to build a performance-indicator framework for identifying the key factors affecting the sustainable development of such tourism. Following a similar general approach to those of the studies cited above, the present research will establish performance indicators for the operations management of eco-museums, using FDM for the expert screening of potential indicators, and ANPM for exploring such indicators' interactive influences [20]. Their profiles are provided in Table 1.

Table 1. The Fuzzy Delphi Method and Analytica Network Process Method expert profiles.

\begin{tabular}{|c|c|c|c|}
\hline Service Domain & Organization & Title & Expertise \\
\hline \multirow{2}{*}{ Public Sector } & $\begin{array}{l}\text { Nantou County Government } \\
\text { Planning Office }\end{array}$ & Deputy Director & Community Development \\
\hline & National Natural Science Museum & Associate Researcher & $\begin{array}{l}\text { Natural Resources Management; } \\
\text { Community Empowerment }\end{array}$ \\
\hline \multirow{5}{*}{ Private Sector } & Wuguan Art Co., Ltd. & Director & $\begin{array}{l}\text { Museum Strategy Planning } \\
\text { and Presentation }\end{array}$ \\
\hline & $\begin{array}{l}\text { Dacheng Environmental Engineering } \\
\text { Consultant Co., Ltd. }\end{array}$ & General Manager & $\begin{array}{l}\text { Community Empowerment; } \\
\text { Tourism and Recreation Marketing; } \\
\text { Landscape Architecture }\end{array}$ \\
\hline & $\begin{array}{l}\text { Graduate Institute of Museum Studies, } \\
\text { Taipei National University of the Arts }\end{array}$ & Assistant Professor & Museum Operations Management \\
\hline & $\begin{array}{l}\text { Graduate Institute of Conservation of } \\
\text { Cultural Relics and Museology, } \\
\text { National Tainan University of the Arts }\end{array}$ & $\begin{array}{l}\text { Adjunct Associate } \\
\text { Professor }\end{array}$ & Museum Operations Management \\
\hline & $\begin{array}{c}\text { Landscape and Recreation Program, } \\
\text { Feng Chia University }\end{array}$ & Professor & $\begin{array}{c}\text { Community Empowerment; Culture } \\
\text { Industries; Urban Planning }\end{array}$ \\
\hline \multirow{4}{*}{ Academia } & $\begin{array}{c}\text { Department of Landscape and Urban } \\
\text { Design, Chaoyang University } \\
\text { of Technology }\end{array}$ & Professor & $\begin{array}{l}\text { Tourism and Recreation } \\
\text { Marketing; Landscape }\end{array}$ \\
\hline & $\begin{array}{c}\text { Department of Landscape and Urban } \\
\text { Design, Chaoyang University } \\
\text { of Technology }\end{array}$ & Professor & $\begin{array}{l}\text { Museum Operations Management; } \\
\text { Urban Planning; Landscape }\end{array}$ \\
\hline & $\begin{array}{l}\text { Department of Architecture, Chaoyang } \\
\text { University of Technology }\end{array}$ & Assistant Professor & $\begin{array}{l}\text { Community Empowerment; } \\
\text { Culture Industries }\end{array}$ \\
\hline & $\begin{array}{c}\text { Department Cultural and Creativity } \\
\text { and Design, Nan kai University } \\
\text { of Technology }\end{array}$ & Instructor & $\begin{array}{l}\text { Culture Industries; Tourism and } \\
\text { Recreation Marketing }\end{array}$ \\
\hline
\end{tabular}




\subsection{Preliminary Indicator Framework}

This study proposes that eco-museums differ profoundly from both traditional museums and traditional businesses and, therefore, adopted a preliminary indicator framework including community symbiosis, cultural inheritance, and regional revitalization. The relevant literature on each of these dimensions and their impact factors are summarized in Table 2.

Table 2. The dimensions and impact factors of the preliminary indicator framework.

\begin{tabular}{|c|c|c|c|}
\hline Dimension & Impact Factor & Definition of Impact Factors & References \\
\hline \multirow{3}{*}{$\begin{array}{l}\text { Community } \\
\text { symbiosis }\end{array}$} & $\begin{array}{c}\text { Resident } \\
\text { identification }\end{array}$ & $\begin{array}{l}\text { (1) Participants' self-identity: Does the resident agree with the } \\
\text { values of the work of the museum, in terms of both execution } \\
\text { and promotion? } \\
\text { (2) Social value: On the levels of living and the production of } \\
\text { bamboo, does the resident provide the basis for the residents' } \\
\text { ownership and social recognition? }\end{array}$ & {$[21,22]$} \\
\hline & $\begin{array}{l}\text { Community } \\
\text { participation }\end{array}$ & $\begin{array}{l}\text { (1) Community-group support: Does the resident attract the } \\
\text { attention of community groups, promote their actions and } \\
\text { efforts, and establish regional cooperation plans and policies? } \\
\text { (2) Construction of resource networks: Does the eco-museum } \\
\text { establish sustainable-development partnerships with the } \\
\text { community, including government policy-makers and other } \\
\text { decision-making professionals, community workers and } \\
\text { community groups, schools and businesses, and build } \\
\text { resource networks that allow these people and groups to } \\
\text { provide material assistance to one another? } \\
\text { (3) Community and residents' participation: Is there mutual } \\
\text { understanding between the eco-museum and communities, } \\
\text { including at the level of the residents' feelings that can result } \\
\text { in community development, the development of strategic } \\
\text { partnerships, and community support }\end{array}$ & [21-24] \\
\hline & $\begin{array}{l}\text { Local } \\
\text { organization } \\
\text { operations }\end{array}$ & $\begin{array}{l}\text { (1) Bamboo craft association: Does the organization handle } \\
\text { bamboo craft learning courses? } \\
\text { (2) Bamboo craft Development: Does the Bamboo craft } \\
\text { promote local employment and economic development? }\end{array}$ & [25] \\
\hline \multirow[t]{3}{*}{$\begin{array}{l}\text { Cultural } \\
\text { inheritance }\end{array}$} & $\begin{array}{l}\text { Preservation } \\
\text { of cultural } \\
\text { heritage }\end{array}$ & $\begin{array}{l}\text { (1) Preservation of historical value: Do the eco-museum's } \\
\text { industrial-history preservation efforts include activities and } \\
\text { processes that are both representative and important? } \\
\text { (2) Preservation of intrinsic value: Does the eco-museum } \\
\text { preserve the cultural heritage of intrinsic value, including } \\
\text { landscapes that form textures, layouts/configurations, } \\
\text { elements, and industrial structures, as well as literature, } \\
\text { intangible memories, and customs? } \\
\text { (3) Collection and preservation measures: Has the } \\
\text { eco-museum adopted standard operating procedures for } \\
\text { collection and preservation, including but not limited to } \\
\text { disaster prevention, records management, and inspection of } \\
\text { building conditions? }\end{array}$ & [21-23] \\
\hline & $\begin{array}{l}\text { Presentation } \\
\text { of cultural } \\
\text { values }\end{array}$ & $\begin{array}{l}\text { (1) Cultural exhibition: Has the eco-museum developed } \\
\text { policies and plans for its exhibitions? } \\
\text { (2) Overall presentation: Does the eco-museum preserve the } \\
\text { context of industrial cultural heritage? }\end{array}$ & [22] \\
\hline & $\begin{array}{l}\text { Promotion of } \\
\text { cultural } \\
\text { activities }\end{array}$ & $\begin{array}{l}\text { (1) Organizing local festivals: Does the eco-museum organize } \\
\text { large-scale events and seminars, and communicate with other } \\
\text { museums or academic institutions? } \\
\text { (2) Museum-activities promotion: Does the eco-museum } \\
\text { adequately communicate about its objectives/philosophy and } \\
\text { events/exhibitions? }\end{array}$ & {$[21,24]$} \\
\hline
\end{tabular}


Table 2. Cont.

\begin{tabular}{|c|c|c|c|}
\hline Dimension & Impact Factor & Definition of Impact Factors & References \\
\hline \multirow{4}{*}{$\begin{array}{l}\text { Regional } \\
\text { revitalization }\end{array}$} & $\begin{array}{l}\text { Local brand } \\
\text { marketing }\end{array}$ & $\begin{array}{l}\text { (1) Community image design and marketing: Does the } \\
\text { eco-museum promote community resources and engage in } \\
\text { healthy and dynamic marketing activities? (2) Establish brand } \\
\text { characteristics: Does the eco-museum's branding include } \\
\text { regional environmental and/or cultural features? (3) Rich and } \\
\text { lively Internet information: Has the eco-museum established } \\
\text { an online presence that includes a marketing platform? }\end{array}$ & {$[22,24,25]$} \\
\hline & $\begin{array}{l}\text { Satisfaction of } \\
\text { tourists' } \\
\text { requirements }\end{array}$ & $\begin{array}{l}\text { (1) Visitors' participation satisfaction: Are visitors to the } \\
\text { eco-museum satisfied and willing to visit again? } \\
\text { (2) Visitor opinion survey: Does the eco-museum regularly } \\
\text { assess the public's interest in its exhibitions, services and } \\
\text { facilities, and willingness to share experiences after visits? }\end{array}$ & [21] \\
\hline & $\begin{array}{c}\text { Local } \\
\text { industrial } \\
\text { development }\end{array}$ & $\begin{array}{l}\text { (1) Appropriate work team: Does the eco-museum have } \\
\text { appropriate professional workgroups and sufficient } \\
\text { manpower to facilitate industrial transformation? } \\
\text { (2) Trade alliances: Does the eco-museum leverage the } \\
\text { industrial environment and regional resource characteristics } \\
\text { to create business opportunities and new value links, for } \\
\text { example, by establishing tourist trails? }\end{array}$ & {$[22,24]$} \\
\hline & $\begin{array}{l}\text { Environmental } \\
\text { improvement }\end{array}$ & $\begin{array}{l}\text { (1) Meeting public needs: Does the eco-museum reuse space } \\
\text { and utilize it in ways that meet public needs? } \\
\text { (2) Improving the health of the environment: Does the } \\
\text { eco-museum make efforts to restore the environment and } \\
\text { rebuild friendly relations between people and } \\
\text { the environment? } \\
\text { (3) Creating local features: Does the eco-museum use } \\
\text { community resources to create local features, including the } \\
\text { integration of social production with the local landscape to } \\
\text { create a community/landscape image that is recognized by } \\
\text { local residents? }\end{array}$ & {$[22,25]$} \\
\hline
\end{tabular}

\section{Results and Discussion}

\subsection{Analysis of the FDM Questionnaire Results}

All of this study's FDM items were scored from 0 to 10; the higher its score, the more important an influence factor is, according to the expert's individual professional experience. Statistics were collected using the Microsoft Excel 2010 software, according to the method of double-triangular fuzzy ambiguity and gray zones proposed by Cheng [26]. A threshold value of 6 was set as the pass score, and the remaining factors below the threshold of 6 were deleted. The results are shown in Table 3 .

In the first stage of FDM, all indicators passed the consistency check. However, the local brand marketing impact factor of the regional revitalization dimension scored 5.80, that is, below the threshold of 6 , and so was removed from the framework. Overall, these results reflected the 11 sampled experts' shared belief that community symbiosis and cultural inheritance are more important than regional revitalization; and that within these two dimensions, the impact factors of community participation and preservation of cultural heritage are particularly important influence factors, with community participation receiving the highest overall score, 7.71. Those experts with backgrounds in the cultural industries and community empowerment tended to give the lowest scores to the regional revitalization dimension. 
Table 3. The impact factors of eco-museum and operations-management performance.

\begin{tabular}{|c|c|c|c|c|c|c|}
\hline \multirow{2}{*}{ Aspects } & \multirow{2}{*}{ Impact Factor } & Maximum Ci & Minimum Oi & \multicolumn{2}{|c|}{ Best Value } & \multirow{2}{*}{$\begin{array}{l}\text { Expert Consensus } \\
\text { Value (Gi) }\end{array}$} \\
\hline & & \multicolumn{2}{|c|}{ Geometric Mean } & MIN & MAX & \\
\hline \multirow{3}{*}{$\begin{array}{l}\text { Community } \\
\text { Symbiosis }\end{array}$} & Resident identification & 8.78 & 6.40 & 6.00 & 9.00 & 7.50 \\
\hline & Community participation & 8.96 & 6.45 & 7.00 & 9.00 & 7.71 \\
\hline & $\begin{array}{c}\text { Local organization } \\
\text { operations }\end{array}$ & 8.06 & 5.85 & 5.00 & 8.00 & 6.43 \\
\hline \multirow{3}{*}{$\begin{array}{l}\text { Cultural } \\
\text { inheritance }\end{array}$} & $\begin{array}{l}\text { Preservation of } \\
\text { cultural heritage }\end{array}$ & 8.79 & 6.22 & 6.00 & 9.00 & 7.51 \\
\hline & $\begin{array}{l}\text { Presentation of } \\
\text { cultural values }\end{array}$ & 8.60 & 6.28 & 6.00 & 8.00 & 7.50 \\
\hline & $\begin{array}{c}\text { Promotion of } \\
\text { cultural activities }\end{array}$ & 8.06 & 5.83 & 6.00 & 8.00 & 7.40 \\
\hline \multirow{4}{*}{$\begin{array}{c}\text { Regional } \\
\text { Revitalization }\end{array}$} & Local brand marketing & 7.43 & 4.83 & 4.00 & 8.00 & $5.80 *$ \\
\hline & $\begin{array}{l}\text { Satisfaction of tourists' } \\
\text { requirements }\end{array}$ & 7.28 & 4.91 & 5.00 & 8.00 & 6.43 \\
\hline & $\begin{array}{c}\text { Local industrial } \\
\text { development }\end{array}$ & 8.28 & 5.79 & 5.00 & 8.00 & 6.89 \\
\hline & $\begin{array}{l}\text { Environmental } \\
\text { improvement }\end{array}$ & 7.74 & 5.62 & 5.00 & 8.00 & 6.57 \\
\hline
\end{tabular}

Note: * This indicator did not reach the threshold value of 6 and was eliminated from further consideration.

\subsection{Analysis of the ANPM Questionnaire Results}

Next, the impact factors that remained following the phase-1 screening were analyzed by ANPM. The multi-criterion decision software Super Decisions was used to calculate the weight values and the consistency of the questionnaire was checked before confirming whether it was valid. If the C.I. (Consistency Index) value is $\leq 0$, it is consistent with the degree of conformity; otherwise, it is not. In this phase of the study, a total of nine expert questionnaires were collected. After passing the consistency check, all were deemed valid.

The geometric averaging method was used to arrive at the experts' relative importance of each indicator. The ranked weights of community symbiosis, cultural inheritance, and regional revitalization are shown in Table 4. Community symbiosis (weight 0.41074 ) was again found to be the most important, followed by cultural inheritance (weight 0.34362), and regional revitalization (weight 0.24564).

Table 4. The dimensions ranked by weights.

\begin{tabular}{ccc}
\hline Dimension & Weight & Ranking \\
\hline Community Symbiosis & 0.41074 & 1 \\
Cultural Inheritance & 0.34362 & 2 \\
Regional Revitalization & 0.24564 & 3 \\
\hline
\end{tabular}

In phase 2, however, the preservation of cultural heritage was the most important impact factor, accounting for 0.1698 . The residents' identity and community participation were ranked joint second, accounting for 0.1467 apiece. The three lowest rankings were assigned to environmental improvement (0.0940), promotion of cultural activities (0.0653), and satisfaction of tourists' requirements (0.0495). The full results are shown in Table 5.

In other words, the nine experts surveyed in phase 2 expressed a collective belief that the most important dimension of eco-museums' operations-management performance was community symbiosis and that three influence factors-preservation of cultural heritage (0.1698), resident identification (0.1467), and community participation (0.1467) —were more important than the other six. 
The traditional museum's mode of operations focuses on the preservation, restoration, and maintenance of cultural relics, as well as the control and promotion of the museum's affairs by museum professionals. The results of the present study show that experts believe that these cultural-inheritance concerns are the most important aspects of eco-museums' operations-management performance. In contrast to the traditional museum, the eco-museum emphasizes people-oriented and resident-based operations, and advocates community members' active participation in and construction of a sense of identity between locality and culture.

Table 5. The factors influencing the ranking of the impact factors of operations-management performance.

\begin{tabular}{|c|c|c|c|c|c|}
\hline Objective & Dimension & Impact Factor & $\begin{array}{l}\text { Relative } \\
\text { Weight }\end{array}$ & $\begin{array}{l}\text { Absolute } \\
\text { Weight }\end{array}$ & Ranking \\
\hline \multirow{9}{*}{$\begin{array}{l}\text { Operations-management } \\
\text { Performance of } \\
\text { Eco-museums }\end{array}$} & \multirow{3}{*}{$\begin{array}{l}\text { Community } \\
\text { symbiosis }\end{array}$} & Resident identification & 0.35714 & 0.1467 & 2 \\
\hline & & $\begin{array}{l}\text { Community } \\
\text { participation }\end{array}$ & 0.35714 & 0.1467 & 2 \\
\hline & & $\begin{array}{l}\text { Local organization } \\
\text { operations }\end{array}$ & 0.28572 & 0.1174 & 4 \\
\hline & \multirow{3}{*}{$\begin{array}{c}\text { Cultural } \\
\text { inheritance }\end{array}$} & $\begin{array}{l}\text { Preservation of } \\
\text { cultural heritage }\end{array}$ & 0.49424 & 0.1698 & 1 \\
\hline & & $\begin{array}{l}\text { Presentation of } \\
\text { cultural values }\end{array}$ & 0.31568 & 0.1085 & 5 \\
\hline & & $\begin{array}{c}\text { Promotion of cultural } \\
\text { activities }\end{array}$ & 0.19008 & 0.0635 & 8 \\
\hline & \multirow{3}{*}{$\begin{array}{l}\text { Regional } \\
\text { revitalization }\end{array}$} & $\begin{array}{l}\text { Satisfaction of tourists' } \\
\text { requirements }\end{array}$ & 0.41564 & 0.1021 & 6 \\
\hline & & $\begin{array}{l}\text { Local industrial } \\
\text { development }\end{array}$ & 0.20170 & 0.0495 & 9 \\
\hline & & $\begin{array}{l}\text { Environmental } \\
\text { improvement }\end{array}$ & 0.38266 & 0.0940 & 7 \\
\hline
\end{tabular}

4.3. Analysis of the Potential Operations-Management Performance of a Bamboo Crafts Museum in the Jhushan Township

\subsubsection{Community Symbiosis}

In recent years, the Jhushan's government and regional associations of residents and organizations have focused on the importance of bamboo culture, as well as its decline. This recognition has driven efforts to preserve it, including support for bamboo craftspeople, craft homes and bamboo craft workshops, training in bamboo artistry, and the development of a community plan. The local government, the Bamboo Culture Park, and the Jhushan Local Cultural Museum have all held cultural events and promoted the above-mentioned resources.

\subsubsection{Cultural Inheritance}

Preservation of cultural heritage. The preservation and promotion of Jhushan's bamboo cultural heritage, whether by public- or private-sector organizations or individual residents, has been actively pursued in recent years. Such activity is at the core of cultural preservation as engaged in by eco-museums. However, developing a talent in bamboo crafts takes a long time and is difficult to pass on; and it remains the main focus of Jhushan Township's ongoing promotional efforts.

Presentation of cultural values. The household containers used by local people in early Jhushan were mostly made of bamboo but, as noted above, these have gradually been replaced by less expensive products, and the area's bamboo crafts have gradually declined. The consciousness of its disappearance has led to the promotion of the bamboo arts via activities, exhibitions, and courses. For the eco-museum, the question is whether the cultural value of bamboo can be fully presented. Here, the importance of 
the sheer longevity of the tradition should not be underestimated as it connects to sustainability, as well as to cultural values.

Promotion of cultural activities. Jhushan Town's active promotion of bamboo craft activities has included bamboo culture festivals, bamboo crafts forums and courses, and local organizations' creation and promotion of crafts communities. According to Horng, many local residents believed that festivals related to bamboo crafts had not been promoted well throughout the country, but that they could enhance the image of these crafts-and of local people-if such promotion was effective. For the local economy, the development and exchange of bamboo arts and crafts has been positive, but due to poor national-level promotion, it has not reached its full potential [27].

\subsubsection{Regional Revitalization}

Satisfaction of tourists' requirements. The Jhushan residents' organization promotes a special-purpose accommodation program that brings expertise from all over the country to give back to Jhushan. Efforts to enable tourists to better understand Jhushan's culture have also indirectly affected its development. As Tsai observed, a survey of bamboo-crafts management in Jhushan found that tourists mainly went there for its natural scenery, with bamboo products being of secondary importance [28]. Lin's study of tourism imagery of Jhushan and visitor intentions regarding Jhushan likewise found that the promotion of bamboo imagery was insufficient [29].

Local industrial development. In recent years, the local organization Townway, which is active in Jhushan, has collaborated with other organizations in providing platforms for action, practical training courses for bamboo nests, collaborative design of local products, and promotion programs such as marketing and specialty exchange. Other local entities have also actively promoted the preservation, promotion, and transformation of bamboo crafts, and this has brought new vitality to Jhushan and stimulated the development of local industries. However, the Jhushan Township's overall crafts scene is dominated by bamboo crafts workshops, factories, wholesalers, and retailers. Most technologies remain in the primary stage, and those involved must continue to work hard to promote the development of other local industries.

Environmental improvement. Jhushan has plans to facilitate better relations between people and the natural environment, linked to its promotion of several crafts communities.

To sum up, the present exploration of the bamboo-crafts resources of Jhushan Township through the lens of eco-museum operations-management performance has revealed that the area's promotion of cultural activities, the satisfaction of tourists' requirements, the transformation of local development, and local industrial development are still insufficient. The booming development of Jhushan's bamboo crafts is, in eco-museum terms, a sign of the flourishing of community symbiosis and the preservation of cultural inheritance. However, regional industrial development and rejuvenation, despite local organizations' active promotion of business opportunities, has stalled due to problems of industrial restructuring, marketing, and the difficulties inherent in passing on traditional bamboo-crafts techniques. These problems must be solved if the establishment of a bamboo eco-museum in Jhushan Township is to be a success.

\section{Conclusions}

The present effort to establish a measurement framework for the operations-management performance of eco-museums had to confront the challenge that the eco-museum concept itself is idealized and romanticized to an unhelpful degree. Realistically, the operating expenses, manpower, and local resources required by eco-museums are limited by their localities. The creation and operation of eco-museums must also be based on community empowerment, as when residents conserve and promote their culture together, this indirect promotion and reinforcement of localities' positive images can enhance such museums' overall development and operation. Therefore, before an eco-museum is established or targets are set for its performance, its founders should have a clear understanding of the 
characteristics of the region and the resources it possesses. This will allow the museum to present its most authentic face to everyone and, thus, truly belong to the region.

The present study's framework, established through FDM followed by ANPM, found that among the three main dimensions-community symbiosis, cultural inheritance, and regional revitalization - the third was deemed least important by experts; and within the former two dimensions, the three most important impact factors were the preservation of cultural heritage (cultural inheritance), resident identity (community symbiosis), and community participation (community symbiosis). Jhushan Township's bamboo crafts have a long history and rich resources, and changes in its bamboo industry mirror changes in the lifestyles of its residents. The present analysis suggests that the community symbiosis and cultural inheritance of a potential Jhushan bamboo eco-museum are strong, especially due to the energy and enthusiasm of the Jhushan Township's local organizations. With firm support from the public sector, further community empowerment, and greater efforts to preserve bamboo-crafts skills, the foundations for the development of a successful eco-museum can be effectively laid. For cultural heritage literature, this paper contributed to the understanding of the diverse preservation methods of the bamboo culture and the development context and operation management of the bamboo draft. For ecotourism researchers, through the participation of local residents, they can gain a deeper understanding of the bamboo draft and experience the combination and application of bamboo draft culture and life. To outline the importance of nature protection, bamboo has an impact on the development of the Jhushan area, as well as its industrial and economic impact. For industrial development, the development of the bamboo craft from the daily necessities to bamboo artworks could be analyzed to investigate the development and changes of the bamboo craft.

Author Contributions: All four authors significantly contributed to the scientific study and writing. Project Administration, K.-W.H.; Resources, M.-L.L.; Writing-Review \& Editing \& Original Draft Preparation, J.-C.C.; Writing-Original Draft Preparation, S.-F.H.

Funding: This research received no external funding.

Acknowledgments: We would like to thank the anonymous reviewers for their helpful suggestions and feedback as well as the 11 experts' public sector, private sector, and academia circles to help answer the questionnaire.

Conflicts of Interest: The authors declare no conflict of interest.

\section{References}

1. Chang, Y.-T. The Eco-Museum in Taiwan: Background and Current Status of Development; China Museum-Guizhou Eco-Museum Group Built and Eco-Museum International Altar Album: Guizhou Province, China, 2005; Volume 3, pp. 68-72.

2. Chang, L.L. The Study on Eco-Museum and Development of Regional Culture-The Case of Lan-Yang Museum. Master's Thesis, Institute of Traditional Arts, Taipei National University of the Arts, Taipei, Taiwan, 1998.

3. Chen, H.-Y. A Study of Eco-Museums-By the Example of the Museum of Gold; Department of Fine Arts, National Taiwan Normal University: Taipei, Taiwan, 2007.

4. Liu, B.-L. A Study of Liouduai Hakka Cultural Park from an Ecomuseum Theory. Master's Thesis, Institute of Arts Management, National Sun Yat-sen University, Kaohsiung, Taiwan, 2008.

5. Huang, L.-H. Research on the Influence of Integrated Community Construction from an Eco-Museum Perspective-A Case Study of Shihsanhang Museum. Master's Thesis, Graduate Institute of Business Administration, National Chengchi University, Taipei, Taiwan, 2009.

6. Taiwan Map ONLINE. Available online: http:/ / www.safetourbus.com (accessed on 22 October 2017).

7. Riviere, G.H. The Ecomuseum: An evolutive definition. Mus. Int. 1985, 148, 182-183. [CrossRef]

8. Cultural Inheritance of Humanity. ICOM code of ethics for museums. Int. J. Cult. Prop. 2006, 13, $393-408$.

9. Chang, Y.-T. Analysis of Planning Concepts and Cases of Eco-Museum. Museol. Q. 1996, 10, 9-10.

10. Chen, M.-S.; Kuo, L.-J. The Impacts of Strategic Leadership on Organizational Performance: Taking Learning Organization as the Intervening Variable. J. Bus. Adm. 2004, 63, 27-66. 
11. Chiou, C.-H. Leadership Strategies and Organizational Performance Management. J. Public Adm. 2008, 26, 37-69.

12. Chen, F.-C.; Fang, H.-K.; Wang, M.-Y. A Case of Study on the Performance of Nonprofit Organization from the Intellectual Capital. J. Chin. Trend Forw. 2007, 3, 133-152.

13. Chan, P.-H.; Chen, W.-J. The Viewpoint of BSC on the Performance of Incorporating Public Kindergartens with Public Nursery-schools. Forum Educ. Adm. 2009, 1, 81-111.

14. Lin, Y.-N. Research on Japanese Museum Evaluation System; Research Report; Japan-Taiwan Exchange Association: Taipei, Taiwan, 2012.

15. Zhang, H.; Wey, W.-M.; Chen, S.-J. Demand-Oriented Design Strategies for Low Environmental Impact Housing in the Tropics. Sustainability 2017, 9, 1614. [CrossRef]

16. Dalkey, N.C.; Helmer, O. An experimental application of the Delphi method to the user of experts. Manag. Sci. 1963, 9, 458-467. [CrossRef]

17. Delbecq, A.L.; van de Ven, A.H.; Gustafson, D.H. Group Techniques for Program Planning: A Guide to Nominal Group and Delphi Processes; Scott, Foresman and Company: Glenview, IL, USA, 1975.

18. Liu, Y.-Y.; Chiu, Y.-H. Evaluation of the Policy of the Creative Industry for Urban Development. Sustainability 2017, 9, 1009. [CrossRef]

19. Kao, L.-S.; Chiu, Y.-H.; Tsai, C.-Y. An Evaluation Study of Urban Development Strategy Based on of Extreme Climate Conditions. Sustainability 2017, 9, 284. [CrossRef]

20. Wang, S.-H.; Lee, M.-T.; Château, P.-A.; Chang, Y.-C. Performance Indicator Framework for Evaluation of Sustainable Tourism in the Taiwan Coastal Zone. Sustainability 2016, 8, 652. [CrossRef]

21. Liu, W.-C. A Study on the Performance Measures in Museums: Using the Museum of New Zealand Te Papa Tongarewa and National Palace Museum as Examples. Museol. Q. 2008, 22, 109-125.

22. Tsai, Y.-M. Developing Evaluation Indicators of Industrial Heritage Reused Study. Master's Thesis, Graduate Program of Sustainable Tourism and Recreation Management, National Taichung University of Education, Taichung, Taiwan, 2012.

23. Liang, G.-Y. On Regular Museum Assessment. Museol. Q. 2004, 18, 145-154.

24. Wang, W.-Y. A Study of Governmental Museum's Operational Index with Balanced Scorecard Analysis-Using Shihsanhang Museum of Archaeology as an Example. Master's Thesis, Graduate Program of Educational Innovation and Assessment, National Taipei University of Education, Taipei, Taiwan, 2011.

25. Wu, K.-L. Developing an Evaluation Framework for Community Empowerment from the Viewpoint of Sustainable Communities: A Study on the Experiences of Tainan City and Tainan County. J. Hous. Stud. 2007, 16, 21-55.

26. Cheng, T.-B. Fuzzy Assessment Model for Maturity of Software Organization in Improving Its Staff's Capability. Master's Thesis, Department of Information Management, National Taiwan University of Science and Technology, Taipei, Taiwan, 2001.

27. Horng, Y.-C. Study on Local Effect and Evaluation of Bamboo Cultural Festival in Zhu-Shan, Nantou. Master's Thesis, Department of Industrial Design, National Yunlin University of Science Technology, Yunlin County, Taiwan, 2005.

28. Tsai, T.-Y. Study on Investigation of Bamboo Forest Management Situation and Its Development Feasibility into Leisure in Jushan Area. Master's Thesis, Department of Forestry, National Chung Hsing University, Taichung, Taiwan, 2005.

29. Lin, Y.-H. The Study on the Impact of Tourism Image and Word of Mouth of Local Culture Industry on Travel Intension-As an Example of Tea Industry from Zhushan, Mingiian, Yuchi and Lugu Townships, Nantou County. Master's Thesis, Graduate Institute of Bio-Industry Management, National Chung Hsing University, Taichung, Taiwan, 2017.

(C) 2018 by the authors. Licensee MDPI, Basel, Switzerland. This article is an open access article distributed under the terms and conditions of the Creative Commons Attribution (CC BY) license (http:// creativecommons.org/licenses/by/4.0/). 